\title{
Solar Photovoltaic Energy Infrastructures, Land Use and Sociocultural Context in Portugal
}

Luís Silva ${ }^{1}$ and Siddharth Sareen ${ }^{2,3}$

${ }^{1}$ Centre for Research in Anthropology, New University of Lisbon (CRIA NOVA FCSH), Lisbon, Portugal; luis.silva98@gmail.com

${ }^{2}$ Department of Geography and Centre for Climate and Energy Transformation, University of Bergen, Bergen, Norway

${ }^{3}$ Department of Media and Social Sciences, University of Stavanger, Stavanger, Norway

in: Local Environment, DOI: 10.1080/13549839.2020.1837091, https://tandfonline.com -- Please, cite published version --

\begin{abstract}
Energy infrastructures co-evolve with and are enacted and acted upon by not only technical but also regulatory and institutional factors, as well as sociocultural contexts. As solar energy plants require access to land and the electric grid, the recent uptick in solar energy infrastructure features interplay with local specificities. This article thus examines the uptake of solar energy in Portugal at both the national and local scales. The purpose is to contribute to a timely debate on critical renewabilities and to provide valuable insights for the future rollout of solar photovoltaic (PV) capacity in Portugal. The study demonstrates that solar energy policy measures not only show some start-stop aspects of the utility-scale solar PV roll-out, but have also tended to favour large companies, rather than community or individual operators. Three case studies point to a range of public attitudes regarding solar PV roll-out and its underlying drivers that are locally influenced by land use and sociocultural contexts, apparently more so than by concerns of low-carbon energy transitions. A key point for future solar energy transitions is, therefore, that local communities' concerns should be understood and approached cross-sectorally. Furthermore, the intersection of energy transitions and justice must be considered from a multi-scalar, multi-sited and cross-sectoral perspective.
\end{abstract}

\section{Keywords}

Solar power; energy infrastructures; land use; sociocultural context; Portugal 


\section{Introduction: Critical renewabilities and multi-scalar solar energy uptake in Portugal}

Two contrasting developments are taking shape in recent scholarship within energy geographies and energy anthropology: the former increasingly engages with the socio-spatial and justice aspects of renewable energy uptake (e.g., Bridge et al. 2013; Huber 2015), while the latter focuses on the problems that renewable energy uptake creates or exacerbates (e.g., Dunlap 2019; Howe and Boyer 2016; Watts 2018). There is mature consideration of the full consequences of the massive socio-material changes to energy systems that constitute energy transitions, and a problematisation of whether we are really witnessing a low-carbon transition. But there is also reason to wonder whether scholarship is taking being critical too far in deconstructing renewable energy uptake: many of the problems this is beset by are symptomatic of the relatively inequitable nature of socioeconomic systems, and of the fact that renewable energy sources still compete in a sector where most factors favour fossil fuels. Whether it is historical institutional structures, the embodied memories of sectoral actors, existing large-scale energy infrastructures or the centralised nature of decision-making and access to large financial capital, renewable energy sources and the actors trying to champion them have their work cut out, especially if they are not large, powerful actors themselves (Cowell et al. 2017; Sareen and Haarstad 2018).

This emerging field of enquiry is increasingly referred to as "critical renewabilities", ${ }^{1}$ and overlaps with some concerns often dealt with in work on energy and ethics (cf. Smith and High 2017; Sovacool 2013). Some key questions in this field concern whether we as scholars should take a normative stance, and what implications this would have for the ethnographic work we do, and for the empirical and theoretical insights we contribute on its basis.

In this paper, we approach and unpack these abstract questions by engaging - as a social anthropologist and a human geographer - with the concrete case of solar energy uptake. Solar photovoltaics (PV) has witnessed remarkable cost declines over the past two decades (Chase 2019). In 1999, the global cumulative installed capacity of solar PV was 1 Giga Watt (GW) and increased to more than $635 \mathrm{GW}$ in 2019 (Jäger-Waldau 2020). In addition, electricity generation costs from solar PV decreased from around $€ 0.5 / \mathrm{kWh}$ in 2000 to a worldwide average below $€ 0.05 / \mathrm{kWh}$ in 2019 (Vartiainen et al. 2020). Our study tackles this issue in Portugal at both the national and local scales. We demonstrate empirically how the governance of such energy infrastructural interventions requires navigating a complex maze of crosssectoral intersections with land use and sociocultural contexts. Our main argument is that multiple actors involved in environmental governance must be cognisant of and attend to these 
intertwined issues for a fuller appreciation of how to enable appropriate energy infrastructure transitions in a given context.

The paper is structured as follows. After presenting the study methods, we outline the spatiotemporality of the solar PV rollout in Portugal. Then, we put forward an analysis of three case studies. Next, we discuss the research results and reflect on the implications of these findings for the future rollout of solar uptake in Portugal, and for academic practice. In particular, we ask: Does a neglect of legitimacy in the selective representation of concerns characterise solar energy uptake, and does this offer a fuller picture of why some actors have protested the rollout of this infrastructure? This is a preliminary step towards addressing where energy geographies and energy anthropology stand in relation to the emerging critical renewabilities strand. Such a move is essential in order to discuss and establish morally defensible and intellectually generative approaches to the ethnographic study of energy infrastructure roll-out. This is vital for low-carbon transitions but appears to have mixed effects for social equity due to existing uneven socio-spatial patterns, as our findings demonstrate. We conclude with implications for epistemic politics and environmental governance in support of sustainability transitions, and underscore that these concerns are not limited to the energy sector. Rather, they intersect with other concerns like land use and sociocultural contexts, within which energy systems and their infrastructural changes are deeply imbricated.

\section{Study methods}

This article draws upon multiple sources of material. First, there is material from a wider investigation of renewable energy transitions carried out by both authors in Portugal. Research in the early 2010s focused on wind and solar farms. This involved the lead author examining the social attitudes towards these energy facilities, their contribution to local development, and their effects on tourism (e.g., Delicado, Figueiredo, and Silva 2016; Silva and Delicado 2017) since 2013. Then, the research tackled solar energy rollout. Conducted by the co-author since 2017, the latter study aimed to scrutinise the governance and accountability of solar energy uptake (e.g., Sareen 2020; Sareen and Haarstad 2018). The studies have been developed at both the national and local scales, and draw on interviews with stakeholders (over 200 in the first study and 80 in the second one) and multi-sited field observations, including in the three case study locations under analysis in this paper. This was complemented by an online survey conducted by the lead author with residents of Amareleja ( $n=18$, including 9 females) and Alcoutim ( $n=32$, including 19 males) during autumn 2019. The survey was structured on the respondents' perceptions and attitudes towards solar energy in Portugal and the 
village/municipality under study. Topics included: solar energy generation and utilisation; utility owned solar farms in the village/municipality; benefits; concerns; and the links between solar farms and tourism.

Second, this paper is based on various sets of secondary sources of information: energy sector legislation, policy papers and programmes, thematic online grey literature, two Eurobarometer surveys (Eurobarometer 65.3 of 2007 and Eurobarometer 490 of 2019), scientific publications, Public Consultation Reports of Environmental Impact Assessment (EIA) and Environmental Effect Assessment (EEA) processes regarding solar farms from the Portuguese Environment Agency, statistics produced by the Directorate General for Energy and Geology (DGEG), and civil society publications.

The focus is on three case studies in southern Portugal: the PV power plant of Amareleja, in the Alentejo region, and the PV power plants of Apra and Alcoutim, in the Algarve region (see Figure 1). The selection of the case studies was based on their location - since solar energy uptake in Portugal has so far taken place largely in these regions, as shown below - and due to differences in the size, developers, and local responses to land use changes associated with these energy facilities when they were developed, as we explain below. The cases thus encompass geographical and sociocultural variation while being clearly comparable. Multiscalarity is a key aspect of case selection, as studies have shown that social justice implications of solar energy rollout vary across scale (e.g., Bouzarovski and Simcock 2017; Sareen and Haarstad 2018; Yenneti, Day, and Golubchikov 2016). This makes our study of interest in other

global solar rollout contexts beyond Portugal as well. The three projects were developed at different time periods, which also gives purchase on the evolution of solar rollout in recent years.

\section{Background: The spatiotemporality of the solar PV rollout in Portugal}

Since the mid-2000s, Portugal has invested extensively in renewable energy sources in line with its international commitments. It met an ambitious target of sourcing $39 \%$ of electricity from renewable sources in 2010 , and raised this to $52.6 \%$ of the grid mix by 2018 , with a target of $60 \%$ by 2020 . In terms of the percentage of renewable energy in its gross final energy consumption, Portugal is at $28.5 \%$ (Eurostat 2018) with a 2020 target of $31 \%$. The main renewable energy sources of electricity are hydro power (44.3\%) (whose inclusion as a renewable energy source is debatable) and wind power (41.3\%), but solar power is gaining importance. In 2018, solar energy comprised $3.3 \%$ of renewable generation, up from $0.8 \%$ in 2010 (DGEG 2019). Driven by cost declines, solar uptake has shown marked recent growth. 
In 2010, only $11 \mathrm{PV}$ power plants greater than 0.25 Mega Watts (MW) of capacity were in operation in Portugal, the first of which became operational in 2007. By December 2018, Portugal had installed nearly 90 PV power plants of such capacity, of which seven are larger than $10 \mathrm{MW}$ and two exceed 15 MW (Amareleja: $46 \mathrm{MW}$ and Ourika: $46.1 \mathrm{MW}$ ) (INEGI/APREN 2019). These PV power plants, of which five are rooftop installations, have a total installed capacity of $673 \mathrm{MW}$ and accounted for $4.8 \%$ of the renewable energy capacity installed on the electric grid by 2018, a sharp increase from the $1.4 \%$ registered by 2010 (134 MW out of 9,682 MW) (DGEG 2019). Most of these large-scale installations are situated in the high solar irradiation regions of Lisbon and the Tagus Valley (24), Alentejo (29) and Algarve (16), mainly in rural areas (see Figure 2). At the end of 2019, there were also about two dozen new large-scale PV power plants under construction, close to half of those licensed (without feed-in tariffs) by the government between 2015 and 2018, totalling 1,500 MW of installed capacity. These new PV power plants are to be built largely in the southern regions of Alentejo and Algarve.

This pattern of development can be explained by the policy framework and the uptake of solar energy by the private sector. The first legislation concerning feed-in tariffs for renewable energy was issued in $1988,{ }^{2}$ then revised in $1999,{ }^{3}$ with the aim of offering stronger financial incentives. In 2001, the 4E programme (Energy Efficiency and Endogenous Energies) ${ }^{4}$ was approved, aiming to achieve $39 \%$ of renewable energy sources in electricity generation within 10-15 years. Successive Energy Policy Plans and the 2010 National Action Plan for Renewable Energies ${ }^{5}$ established more ambitious renewable energy targets and measures to achieve them. Some of these concerned solar energy, such as higher feed-in tariffs, fiscal incentives, green certificates, and funding for research and development projects.

Renewable energy policy suffered a reversal in 2011: the effects of the 2009-2015 economic crisis made themselves felt and a new government renegotiated the feed-in tariff agreements and revised the 2010 National Action Plan for Renewable Energies. ${ }^{6}$ The purpose was to reduce electricity costs and rebalance the renewable energy targets in accordance with reduced demand for electricity. The target for solar energy in 2020 was scaled down from 1,500 MW to $720 \mathrm{MW}$. With the next change of government in 2015, renewable energy policy in general, especially solar energy policy, gained a new impetus. First, under the Great Plan Options for 2016-2019, ${ }^{7}$ the new government aimed to ensure the maintenance of the wind energy cluster already installed in the country, and moreover encourage the emergence of an equivalent cluster of solar energy. Then, under Portugal's National Energy and Climate Plan 
2030 (NECP) (European Commission 2019), ${ }^{8}$ it envisaged the expansion of solar energy to 9 GW over the next decade, including both large- and small-scale photovoltaic installations.

While feed-in tariffs offered for solar energy have historically been higher than for wind energy (Brito et al. 2009), initially high equipment costs and low grid connection limits set by the government (50 MW in 2005, $150 \mathrm{MW}$ in 2010, $720 \mathrm{MW}$ in 2020) hampered PV development until the late 2010s. The first tender for granting rights to connect solar energy to the electricity grid was issued in October 2010, awarding rights for $150 \mathrm{MW}$ split across 75 plots, of which 70 were awarded. From 2010 to 2018, there were no tenders for solar energy. Thereafter, the first auction, for connection rights of up to 1,400 MW split between 24 plots, ${ }^{9}$ was issued in July 2019. This led to $1.15 \mathrm{GW}$ of capacity being successfully auctioned at highly competitive tariffs, notably one instance that went below $€ 15$ per MWh and set a new world record (which was broken in January 2020, marking continued global cost declines in this competitive industrial segment). Overall, auctions achieved a tariff level well below half the annual average price on the Iberian Peninsula wholesale electricity market. Subsequently, the incumbent gas utility GALP Energia acquired 200 MW of solar capacity for Portugal in Spain, and the incumbent energy major EDP (Energias de Portugal) acquired a lot that was not auctioned as it was the sole bidder. This was approved at the third instance of making an offer to settle a tariff corresponding with the average auction outcome. The second auction, for connecting rights of up to $700 \mathrm{MW}$, is scheduled for August 2020.

These energy policy measures have thus far largely favoured companies, rather than community or individual operators, which raises issues of equity. The July 2019 auction, for instance, had a floor of $10 \mathrm{MW}$. Yet, subsequent to the last national elections of October 2019, with the government having been re-elected and the Ministry of Environment and Energy Transition bringing out legislation on community energy, the government has stated an intent to enable household and community-scale solar energy uptake at a faster rate. Large-scale photovoltaic power plant developers comprise a few dozen small and large companies, including international ones. Coopérnico, Portugal's first solar energy cooperative created in 2013, has funded the implementation of a utility-scale solar installation (0.275 MW) and 22 small-scale ones.

Notably, planning decisions on the siting of PV power plants are taken at the national level. Permissions for setting up energy generating facilities are granted by the DGEG, historically under the Ministry of Economy, but since October 2018 under the new Ministry, which combines the environment and energy portfolios. Environmental Impact Assessments (EIA), which are mandatory only for larger PV plants (over $50 \mathrm{MW}$ ) or plants located near existing 
ones, come under the jurisdiction of the Portuguese Environment Agency. Smaller PV projects located in protected and Natura 2000 Network (an ecological land category in Portugal) or National Ecological Reserve sites are required to perform an Environmental Effect Assessment (EEA), whose decision is issued by regional authorities. Until December 2018, 10 EIAs of PV power plants had been conducted, chiefly concerning the construction of new power plants, of which six were conditionally approved, one was rejected and three were ongoing as of December 2019.

Energy generating projects also require the approval of local councils, who must sign an agreement with the developer. Approval is granted in most cases, as developers pay local councils a monthly fee based on the PV power plant revenue. In contrast to wind farms, whose developers have been legally obligated to pay $2.5 \%$ of the monthly revenue since $2001,{ }^{10}$ the taxes paid by PV power plant developers to local councils are negotiated on a case-by-case basis. This nonetheless comprises an important source of additional revenue for local councils. To illustrate the point, several local councils (Castelo Branco, Estremoz, Odemira, Ourique, Pombal, Vila Nova de Foz Côa) have declared new PV power plants under construction or in the process of licensing by DGEG as projects of Municipal Public Interest.

Small-scale solar energy production has been the subject of successive legal regulations since $2002 .{ }^{11}$ These ostensibly aim to promote decentralised low voltage electricity production by individuals and companies by providing incentive schemes and facilitating licensing. However, the initially high cost of technology, declining feed-in tariffs during the early $2010 \mathrm{~s}$, registration fees, low limits to grid connections (413 MW in 2020) ${ }^{12}$ and subsidies set by the government have hindered sustained development in this segment. By December 2018, smallscale solar installations had reached 312.6 MW of installed capacity, a significant increase from the 35.3 MW in 2010 (DGEG 2018; 2019).

Thus, there is an element of scalar bias in the historical trajectory of solar energy uptake in Portugal, as well as some start-stop aspects to the trajectory of utility-scale solar PV power plants that can be linked to specific socio-political developments, as shown above. Building on this overview, we analyse trends in utility-scale solar PV uptake through three case studies in the following section. These accounts complement the national-scale socio-political background presented above with attention to more localised aspects of installing solar capacity. Notably, such accounts include how this energy infrastructure transition intersects with existing land use and diverse situated sociocultural identities in the typically rural, small municipal contexts where such shifts take place. 


\section{How local attitudes towards solar energy intersect with land use and social identity}

Socio-technical imaginaries of solar energy can evoke a markedly different response when considered in abstraction, compared to when they compete with other contextual concerns. Two such concerns are land use, which is altered by installing solar PV infrastructure (cf. McDonald et al. 2009), and social identity, which is a complex artefact that we employ in the terms of Brubaker and Cooper (2000, 4-5) as a "category of practice" used by politicians and ordinary social actors. Extant research shows that the deployment of solar PV power plants has changed land use dynamics and has been at the origin of new land use conflicts (e.g., Calvert and Mabee 2015; Prados 2010). As Grossmann (2019) shows in the case of social housing energy retrofits, conflicts can be a fertile entry point for analysis of energy infrastructural interventions and changing land use (see also Campbell 2016).

According to Eurobarometer data, in the late 2000s, 77\% of Portuguese people were in favour of the use of solar energy, in line with the European Union (EU) average (80\%) (European Commission 2007). More recently, in 2019, 96\% of Portuguese people considered it important that their national government set targets to increase the use of renewable energy, such as wind or solar energy, by 2030, and $97 \%$ were in favour of a carbon-neutral EU by 2050, which is slightly above the EU average (92\%). Additionally, 74\% stated that they have personally taken action to fight climate change in the past six months, well above the EU average of $60 \%$. However, only $4 \%$ had installed solar panels in their home, compared with the EU average of $6 \%$, and just $3 \%$ had changed to an energy supplier that offers a greater share of electricity from renewable sources, well below the EU average of 12\% (European Union 2019). Meanwhile, in the early 2010s, a telephone survey found that not only are Portuguese people more supportive of the construction of new solar power projects than new hydro power, wind power and biomass projects (in the country, municipality or parish), but also that solar panels cause the least Not In My Back Yard reactions of any electricity generation technology: only $13 \%$ of 3,646 respondents showed more preference towards installing them in the country rather than near their residence (Ribeiro et al. 2014).

Despite this, the siting of PV power plants has evoked opposition reactions in some cases; as brought out in the following case studies, this can be attributed mainly to land use conflicts and issues linked to diverse sociocultural identities. In the case studies presented here, we address the rollout of solar PV power plants, and public attitudes and perceptions in relation to such energy infrastructures in the southern regions of Portugal: the Alentejo and Algarve. Before detailing each case, we provide a comparative overview (see Table 1), in terms of key 
characteristics of each solar project: plant size (in MW and hectares), proximate population, solar developer and the period when the plant was developed.

\subsection{The Apra case study}

The Apra PV plant is sited in the Morgado de Apra Farm, in the parish of São Clemente $(17,351$ inhabitants in 2011, estimated 17,200 inhabitants in 2018), close to the boundary between the municipalities of Loulé (70,622 inhabitants in 2011, estimated 68,873 inhabitants in 2018) and São Brás de Alportel (10,662 inhabitants in 2011, estimated 10,416 inhabitants in 2018). The project was promoted and is owned by Sol Cativante, Lda., a company associated with the Glenmont group. The Apra PV plant is divided into two adjacent plots, a $6 \mathrm{MW}$ PV plant and a 4 MW PV plant, occupying an area of 28 hectares. Even though both plants are around the same site, only the $4 \mathrm{MW}$ solar farm was subject to an EIA, since its location encroaches on a Natura 2000 Network site and its connection to the public electricity grid goes through a Natural Ecological Reserve area. The $6 \mathrm{MW}$ plant does not impinge on land with any special ecological functions, according to the Algarve Committee for Regional Development and Coordination (CCDR-Algarve).

The 4 MW PV plant was licensed with a conditional favourable Environmental Effects Decision in October 2012, which required mitigation measures, including an archaeological prospection, a waste management plan during construction, and a landscape integration plan during exploration and construction. According to the EEA, the land area studied for the $4 \mathrm{MW}$ PV plant was largely used for farming activities (88.6\%), with the rest occupied by bush hedges (7.1\%) and holm oak hedges (4.3\%). Both plants, which were awarded under the public tender of 2010, were approved by CCDR-Algarve and DGEG, on the grounds that solar energy would contribute towards balancing the national energy trade and achieving the 2010 National Action Plan for Renewable Energies. This stance was backed up by the local council of Loulé. The PV power plants began to be built in 2013 and became operational in 2014.

From the outset, however, land use change and issues revolving around sociocultural identities proved to be contentious points for the infrastructural intervention. For example, before giving its assent to the project, the council of Loulé voiced concerns to the CCDRAlgarve "regarding the compatibility of the project with Loulé's land plan, the Natura 2000 Network, the National Ecological Reserve, and the operation of the existing heliport in the adjacent project area" ${ }^{13}$

Likewise, the compulsory public consultation period for the $4 \mathrm{MW}$ plant, observed for four weeks till $22^{\text {nd }}$ August 2012 in the regional headquarter town of Faro, received a statement 
signed by approximately 90 residents. ${ }^{14}$ This expressed the citizens' opposition to the project and the "change of status of the land from agricultural to industrial", due to its "impact on the landscape and the microclimate of the surrounding area”. Almargem, an environmental civil society organisation of regional scope based in Loulé, commented via e-mail on $22^{\text {nd }}$ August 2012 that the project would "turn a land of agricultural vocation inserted into a protected area into an industrial space"; this was not taken into consideration.

In addition, a local opposition movement was initiated in 2012 by a British couple, who owned a hillside property directly overlooking the plant. By collecting signatures and sending written statements to the CCDR-Algarve and the Loulé council; sending letters of complaint to the European Commission and a petition to the Ombudsman (copied to the President of the Republic, the President of the Assembly of the Republic, the Prime Minister and the Minister of the Environment); and creating an online public petition (which reached 596 signatures), ${ }^{15}$ the movement sought to prevent the siting of the Apra PV power plant. It considered the plant a threat to a "protected area included in the Natura 2000 network, the rural landscape and the economic activities related to rural and nature tourism”. Although exact figures are unavailable, rural and nature tourism have been promoted to complement and combat the seasonality of sun and beach tourism characteristic of the Algarve region. And the rural character and beauty of the landscape of the area have attracted foreign people to live there, who do not want to live near and look directly at an industrial facility such as a PV power plant, as mentioned by an interviewee in her 50s in 2015.

\subsection{The Alcoutim case study}

The Alcoutim PV power plant (220 MW) is under construction in the parishes of Vaqueiros (497 inhabitants in 2011, estimated 400 inhabitants in 2018) and Martim Longo (1,030 inhabitants in 2011, estimated 900 inhabitants in 2018), in the municipality of Alcoutim (2,917 inhabitants in 2011, estimated 2,244 inhabitants in 2018), since March 2017. The project was proposed by the company Solara4 Energias Renováveis, Lda. and funded by a consortium comprising Irish Welink and Chinese China Triumph International Engineering until 2018, when the investment fund of German insurer Allianz took it over. It stands to be the largest solar plant in Portugal upon completion.

The plant occupies 594 hectares within a fenced property of over 1360 hectares at a former hunting site. As stated in the opinion of the Environmental Impact Assessment Committee within the Portuguese Environment Agency, ${ }^{16}$ land in the study areas of the PV plant and the Power Line corridor is occupied by "Forest and Natural Areas, with about 95\% and 94\% of 
area respectively", predominantly "scrubs, holm oaks Montados, pine tree stands and mixed stands of pine tree with holm oaks and cork oaks", but also "holm oak Montados associated with Cistus scrubs, representing multiple use rural systems of great ecological value".

The project was licensed with a favourable Environmental Impact Decision in December 2015, conditional upon implementing a set of mitigation and compensation measures. These include landscape integration, notably pertaining to the Via Algarviana walking route; ${ }^{17}$ compensating for the destruction of 55 hectares of holm oak Montado and 288 hectares of pine or mixed stands; controlling soil erosion; safeguarding architectural and archaeological heritage sites; and producing plans to monitor flora, vegetation and water resources. Both DGEG and CCDR-Algarve gave their assent to the project on the grounds that solar energy would help Portugal reduce its energy dependence and accomplish the 2010 National Action Plan for Renewable Energies. The council of Alcoutim approved the project as a great contribution to local socioeconomic development, notably regarding job creation. ${ }^{18} \mathrm{~A}$ municipal representative commented in late 2017 that Alcoutim continues to face a serious problem of depopulation and youth out-migration due to lack of jobs.

As in the Apra case study, prospective land use change and conflicts related to some sociocultural identities generated local concern and opposition. Prior to approval, in September 2015, the Municipal Government of Alcoutim voiced concern to the Portuguese Environment Agency regarding the fact that the developer had not requested any licensing for the project despite having completed the EIA. It moreover flagged the visual impact of the project in several villages, changes to the Via Algarviana heritage walking route and agricultural paths, the destruction and erosion of trails, and the negative impact on hunting activities.

The four-week public consultation period concluded on $4^{\text {th }}$ September 2015 in Faro generated 15 written statements, of which 7 came from citizens, 3 from tourism companies, and 1 each from a civil society organisation (Portuguese Society for the Study of Birds, or SPEA), the Cachopo parish council, the Directorate General for Agriculture and Rural Development, the Air Force Staff, and the Brisa group Road Concession, S.A. The last three were not negative, as the PV project "did not clash with the projects within its competence".

Despite being generally supportive of renewable energy generation, all other comments focused on four main topics in expressing opposition to the project: environmental impact, including effects on soil, water resources, local flora and fauna; landscape impact from the visual intrusion of the solar panels; archaeological and cultural heritage impact; and economic impact, most importantly vis-à-vis tourism. Unfavourable comments on economic impact underlined the project's adverse impact on actors dedicated to nature tourism, such as tourist 
accommodation outfits, tourist hunting areas, restaurants and artisans, and on the Via Algarviana walking route and the companies operating around it. ${ }^{19}$ The SPEA requested the relocation of the project for bird protection, particularly for the protection of perched eagles and goshawks.

Almargem opposed the project on the basis that it would occupy and "destroy a 600 hectare mountain area" and "directly affect" 1.4 kilometres of the "Via Algarviana, between the villages Vaqueiros and Furnazinhas", "which will certainly lead to lower the demand from potential hikers, not interested in having to cross an industrial facility of this size, with serious repercussions for the local economy of the villages concerned"; this comment was not considered. ${ }^{20}$ Almargem, which had extensively mapped the heritage route, subsequently changed that section of the Via Algarviana.

A small-scale survey identified other residents' grounds to oppose the project. In spite of their general support for the generation of solar energy, 15 out of 32 respondents expressed opposition to the siting of the PV power plant in Alcoutim due to its perceived negative impact on the landscape, environment and tourism, and due to the lack of benefits for residents. Yet, and by contrast, the other respondents favoured the project's positive impact on the local economy and job creation, its use of abandoned land and the harnessing of endogenous resources. The siting of the PV power plant thus evoked both opposition and Please In My Backyard (PIMBY) reactions; the latter emerge when energy infrastructures are regarded as a source of revenue or other positive economic impact (Pasqualetti 2004; Sowers 2006).

\subsection{The Amareleja case study}

The 46 MW Amareleja PV plant is located in the parish of Amareleja (2,554 inhabitants in 2011, estimated 2,400 inhabitants in 2018), in the municipality of Moura (15,167 inhabitants in 2011, estimated 13,749 inhabitants in 2018). Unlike other PV power plants in Portugal, which were the result of a centralised process of granting installation licenses to companies operating in the energy sector, the Amareleja PV power plant emerged from a local dynamic centred around a small company (Amper Solar) championed by the Municipal Government of Moura and its Mayor. This plant was part of a regional development plan centred around solar energy (Integrated Plan for Sustainable Development of the Municipality of Moura and the Region), which included a manufacturing facility to produce solar panels and local jobs.

In 2006, with the greenfield development for the solar PV plant in place, it was sold to a Spanish company (Acciona). Part of the funds generated were earmarked for local development and allocated to a social fund that supported various projects. One was an incentive scheme for 
domestic rooftop solar energy generation; its funds were exhausted through local demand, and it motivated other Moura residents to seek support to install solar panels (Junqueira, Delicado, and Truninger 2017). Another was a technology park, which took the shape of a solar panel quality testing laboratory (Lógica EM) that was closed in 2019 after failing to turn a profit for several years. Most notably, a solar panel manufacturing facility was constructed in Moura. It imported components from China and was used to assemble panels, with Acciona obligated to employ 100 people for at least 10 years, which it did by subcontracting the operation of the facility. Having honoured this clause, the facility shut down in January 2019, without having created a sustainable local development model for PV manufacturing. Thus, in a variety of ways, the original idea achieved modest successes but failed in its larger long-term aim. A municipal representative interviewed in 2018 mused that Moura continued to grapple with the problem of an aging population and out-migration of skilled youth.

The Amareleja PV plant itself, which occupies 250 hectares and is situated about 300 metres from the village of Amareleja, was licensed in 2005; construction began in 2007 and it became operational in 2008. Most of the occupied area includes wasteland and a deactivated airfield (Cifka Duarte), and belongs to the Amareleja Parish Council, which earns rent. Acciona acquired the remaining land from local owners except a central plot, which sits conspicuously surrounded by solar panels, bearing testimony to an unwilling landowner.

The project was subject to an Environmental Report of the Plant's Urbanization Plan made by the Moura's local council, which was approved, subject to some compensatory measures. These include preserving autochthonous trees (holm oaks), planting 22 hectares of holm oaks in a neighbouring parish (Póvoa de São Miguel), aiding the recovery of the Escaravelho creek, and executing a monitoring plan for birds and fauna on the plant land.

As in the previous cases, land use change encountered some local opposition. The public consultation process received a comment by a citizen who claimed that the plant's visual impact violated the right to the landscape, requested compensation for the devaluation of property adjacent to the site, and asked for reclassification of his own land in line with the land occupied by the plant. The citizen justified the latter point by observing that his request for approval of a rural tourism project had been declined on the grounds that it would occupy National Agricultural Reserve and National Ecological Reserve land. The Moura Municipal Government rejected this request for land reclassification, "which requires a declaration of public interest", and stated that "the damage to the landscape right and the value of the property allegedly caused must be proven". ${ }^{21}$ The complainant filed a lawsuit in the Moura District Court against the installer company claiming a compensation of $€ 600,000$ for material damage 
and $€ 150,000$ for non-material damage, which was considered unfounded. The complainant subsequently appealed to the Supreme Court, which upheld the decision issued by the Moura court. $^{22}$

The plant's construction was also opposed by several other Amareleja residents at an incipient stage for its visual impact on the landscape, perceived health impact and destruction of the airfield as part of local heritage (Delicado et al. 2015; Delicado, Figueiredo, and Silva 2016). This opposition diminished over time, ostensibly in recognition of the land rents that accrued to and were deployed by the Amareleja Parish Council; employment in the construction and maintenance of the plant and in the solar panel factory; the village's rise to prominence in international technological innovation circles and attendant media coverage; and the tourist attraction exerted by the plant (Delicado et al. 2015) in its initial years.

Significantly, while the Apra and Alcoutim PV power plants evoked opposition from residents and were partly viewed as threats to some social identity bases, the Amareleja plant was incorporated in the production of new senses of "locality" (Appadurai 1996). The village adopted the designation "Land of the Sun", which is iterated in the songs of the local choir group and its adoption as the logo of the Amareleja Parish Council (Delicado et al. 2015). This plant led to the creation of a territorial "brand" linked with solar energy generation, also discernible in the use of the sun in promotional material available at the local tourist office and a 10 kilometre walking route named "Rota do Sol" (Route of the Sun), which was created by the Amareleja Parish Council in 2013 and includes the PV power plant. This relates closely to the "demonstration effect" of renewable energy generation projects (del Río and Burguillo 2008), particularly in relation to the touristic attractiveness of local territories.

Importantly, as also noted for wind farms in other parts of Portugal (Delicado, Figueiredo, and Silva 2016), municipal stakeholders' perceptions of the local benefits of large-scale solar installations do not entirely overlap with the perceptions of people living in their vicinity. This signifies a potential gap in the legitimacy of representation. While municipal representatives consider the creation of skilled jobs and the improvement of the quality of life of the local population to be major assets resulting from solar PV plants, the erstwhile mayor of the Amareleja Parish Council and the vast majority of its residents consider these effects to be rather modest (Delicado, Figueiredo, and Silva 2016). In fact, today, as in 2013-2014 (Delicado et al. 2015; Junqueira, Delicado, and Truninger 2017), our online survey in Amareleja revealed a widespread idea that the PV power plant has brought few benefits to the village and its inhabitants. Respondents stated that they hold this view on the grounds that the development has created very few permanent jobs at the local level (15 earlier on, reduced to less than six 
by 2019); has not led to a decline in electricity prices for residents; did not promote the development of other economic activities such as tourism; and did not stop out-migration and desertification. In addition, residents continue to articulate a lack of distributive justice, claiming that the benefits of the solar project accrue primarily to the company that owns the plant and to the Moura Municipal Government and Moura residents. ${ }^{23}$

\section{Discussion}

The above analysis of three diverse cases can be understood as pointing to a range of public attitudes, with overlapping underlying drivers that are deeply influenced by land use and sociocultural contexts, much more so than by concerns for low-carbon energy transitions. For example, in the cases of the Apra and Alcoutim plants, the construction of the solar energy infrastructure has been considered a threat to the "countryside capital", that is, the range of rural resources or products that are bought and sold through tourism (Garrod, Wornell, and Youell 2006) and hence to the tourism-related economic activities already existing in the area as well as to some place-related sociocultural identities. By contrast, the Amareleja plant was initially regarded as a contribution for tourism development, notably for energy tourism development, and led to a reshaping of a sense of local identity. While the success of this reshaping can be debated and requires deeper attention, the directionality is clearly from rural to industrial. Thus, the Amareleja solar infrastructural transition can be understood as an intentional place-making initiative (cf. da Silva and Horlings 2020) that has recursively shaped public perceptions of the cultural meaning of landscapes.

The Alcoutim and the Amareleja case studies also show that economic benefits derived from solar energy generation and its distribution can influence the attitudes and perceptions of residents. The PIMBYism observed among some of Alcoutim's respondents illustrates this point, as occurred with the disappointment of Amareleja residents regarding the local benefits derived from the PV power plant. This research finding is consistent with the findings of studies conducted in other countries, where perceived positive economic impacts increase both local support and the level of planning acceptance of large-scale renewable energy generation projects such as wind farms and solar farms (e.g., Brewkers and Wolsink 2007; Carlisle et al. 2014). It also reinforces the idea that "distributive justice" is a key aspect in residents' perceptions and acceptance of such renewable energy infrastructures (e.g., Delicado, Figueiredo, and Silva 2016; Walker 2014). Transitions in energy infrastructure are thus not limited to socio-technical aspects but involve shifts in ways of living. Bringing solar PV plants 
into being is necessarily accompanied by sociocultural "solar worlding" in dynamic relation with the contextual specificities of land, landscapes and public attitudes.

This indicates that critical renewabilities scholarship risks asking the wrong questions: people's preference for a particular energy source is not necessarily the key concern, because utility-scale solar capacity is not perceived as being locally consumed, or as providing direct local benefits. Rather, what influences people's attitudes and outlook is their experience with and expectation of land use and their deep embeddedness in complex, long-running sociocultural contexts, where solar energy enters as a socio-material intervention. Like any other infrastructure project, and for that matter not a very disruptive one, its terms of entry are crucial - the contrasting experiences stemming from the diverse cases explored above also indicate that these terms are contingent and subject to negotiation. Therefore, a key takeaway for installing future solar capacity is that local communities' concerns should be understood and approached cross-sectorally.

We argue for greater attention to different senses of place, and to whose sense is counted and why (see also Gailing et al. 2019; Mehnen, Mose, and Strijker 2013). Energy infrastructure is tightly interwoven with and impacts other vital domains such as land use and sociocultural landscapes, hence such interventions demand integrated analysis and a situated understanding of the dynamics of socio-material change. Compelling and just explanations must explicitly address and account for the multiple bases for why people have positive dispositions or reservations to change and why some of these come to matter, but not others, in the bureaucratic and technocratic processes through which changes in energy infrastructure are justified and legitimated (see also Sareen et al. 2020).

The Portuguese experience reveals a lack of legitimacy due to patchy representation of concerns, which in part stems from the problem specification that has recently gained wide traction, namely, of installing solar energy capacity as simply being about a "low-carbon energy transition", being inadequate and inaccurate. Solar energy uptake is a change that spans multiple sectors, and thus matters to multiple publics - its impacts on land use and sociocultural context can fly under the radar of decision-makers but matter to other actors, who may feel marginalised and protest as a way to signify their sense of being disenfranchised. A focus on conflicts (Grossmann 2019) and on identity as expressed through practice (Brubaker and Cooper 2000) can provide a more deconstructed, discrete understanding of what is at stake for various actors and interests during energy infrastructural transitions.

This situation is by no means unique to Portugal. In fact, research conducted in other countries shows that the installation of utility-scale renewable energy generation projects may 
give rise to a sense of disenfranchisement among local populations, and limit their autonomy in relation to the use and management of land and other local resources (e.g., Argenti and Knight 2015; Howe 2014; Pasqualetti 2011; Ryser 2019). This is not inevitable. As Scheer $(2004,89)$ argues, the shorter supply chains of solar- and wind-generated electricity may well favour local political autonomy and sovereignty, since they destabilise assumptions and routines established around translocal energy infrastructures and the necessity of grid-based modernity. The range of publics and attitudes across our cases reflects the diverse ways of relating amongst actors associated with energy infrastructure transition projects. This breadth and complexity underscore the need for thick description of how socio-material change is territorialised within sociocultural landscapes. We accordingly argue for the representation and resolution of such entanglements in transitions research on evolving and contested energy geographies.

A reflection on academic practice is that without the multi-scalar, multi-sited study of these cases, it would have been easy to draw rather different conclusions from a far more limited dataset (e.g., that resistance to solar uptake is simply a matter of public perceptions, or that the main challenge is creating local jobs, or that conflicts only relate to acquiring licenses for grid connections and land acquisition). This would have misrepresented the diversity and complexity of the interlinked concerns that are at stake in this energy transition. By reframing the PV project as a specific sort of socio-material intervention, we are able to pose more disaggregated questions that are both generative and open to multiple interpretative insights on a complex issue. As Eriksen (2016, viii) puts it, "the world, or an activity, or an idea" looks different when one moves it up and down the scales. In similar vein, Howe $(2014,383)$ points out that the renewable energy transition "demands attention to multiple scales of engagement: from the places where energy production, distribution, and consumption physically occur to the logics and ethics that guide energy and climate policies".

Notably, land use conflicts related to the installation of solar PV farms may be avoided through the dual use of infrastructure. Examples include the re-use of mining areas (Bódis et al. 2019a), the siting of solar panels on landfills (Szabó et al. 2017) and brownfields (Klusáček et al. 2014), floating PV (e.g., Kougias et al. 2016), agrophotovoltaic systems (Weselek et al. 2019), as well as rooftop installations on commercial sites (Bódis et al. 2019b). Such options are worth considering and prioritising so as to enhance energy justice effects of solar rollout, lower the need for new carbon-intensive transmission infrastructure, and optimise land use. 


\section{Conclusion}

To conclude, we acknowledge that the intersection of energy and ethics raises complex questions that the emerging strand of critical renewabilities aims to address. Our cases demonstrate the importance of approaching this intersection as multi-scalar, multi-sited and cross-sectoral, i.e., located within existing and dynamic energy geographies. These are not only socio-technical matters, but also characterised by how infrastructural change becomes shaped by and embedded in situated political economic structures. This enlarges the picture of energy infrastructure transitions beyond the energy sector, situating it within larger socio-material and sociocultural realities. Our study sheds light on how people perceive certain interventions caused by infrastructural developments and pushes for a more situated understanding of how their lives are affected by these developments.

We argue that such situated analysis can be done by taking a look at the broader picture without undermining the importance of finer details. This can enable scholars to approach renewable energy rollout as the territorialisation of socio-material changes within sociocultural landscapes. In these landscapes, diverse actors articulate their preferences and concerns in an uneven field of power relations and epistemic politics. Our own engagement must be mindful of and respectful towards such difference, in order to ensure that academic work on energy transitions contributes a fuller, evidence-based picture of what is at stake for whom. Research can thus produce actionable knowledge about the mechanisms through which contextual concerns can find representation and resolution in ways that enable low-carbon transitions to sustainable energy futures in complex energy geographies.

\section{Funding}

This work was supported by the Portuguese Foundation for Science and Technology under Grants (SFRH/BPD/93515/2013; DL 57/2016/CP1349/CT0009; CEECIND/01814/2017) and the strategic plans of the CRIA - Centre for Research in Anthropology (UID/ANT/04038/2013; UIDB/ANT/04038/2020); the Bergen Research Foundation under Grant (Project "European cities as actors in climate and energy transformation"); and the University of Bergen - Equinor Akademia Agreement under Grant (Project "Energy transitions”).

\section{Notes}

${ }^{1}$ This is evident in trends at scholarly gatherings, for instance: multiple sessions by this name at the Association of American Geographers 2020 conference, and the content of sessions within the energy geographies research 
group at the Royal Geographical Society - Institute of British Geographers 2019 conference. Also note Ingrid Behrsin's "Critical Renewabilities Lab" at the University of California Davis: https://www.ingridbehrsin.net/critical-renewabilities-lab and her use of the term dating back to 2014 .

${ }^{2}$ Decree-Law n. 189/88, of May 27, 1988.

${ }^{3}$ Decree-Law n. 168/99, of May 18, 1999.

${ }^{4}$ Resolution of the Council of Ministers n. 154/2001, of September 27, 2001.

${ }^{5}$ Resolution of the Council of Ministers n. 63/2003, of April 28, 2003; Resolution of the Council of Ministers n. 169/2005, of October 25, 2005; Resolution of the Council of Ministers n. 29/2010, of April 15, 2010; Resolution of the Council of Ministers n. 29/2010, of April 15, 2010; http://www.ap2h2.pt/download.php?id=27.

${ }^{6}$ Resolution of the Council of Ministers n. 20/2013, of April 10, 2013.

${ }^{7}$ Law n. 7-B/2016, of March 31, 2016.

${ }^{8}$ The NECP aims to achieve $80 \%$ of renewable sources in electricity generation by 2030 , envisaging a target of between $27.4 \mathrm{GW}$ and $27.9 \mathrm{GW}$ in installed renewable energy capacity, also including wind power (9.3 GW), hydro power (between $8.2 \mathrm{GW}$ and $8.7 \mathrm{GW}$ ) and other sources $(0.6 \mathrm{GW})$.

${ }^{9}$ These plots are concentrated in the central and southern regions of the country: centre region (795 MW), Lisbon and Tagus Valley (240 MW), Alentejo (185 MW) and Algarve (30 MW).

${ }^{10}$ Decree-Law n. 339-C/2001, of December 29, 2001.

${ }^{11}$ Decree-Law n. 68/2002, of March 25, 2002; Decree-Law n. 363/2007, of November 2, 2007; Decree-Law n. 118-A/2010, of October 25, 2010; Decree-Law n. 34/2011, of March 8, 2011; Administrative Order n. 430/2012, of December 31, 2012; Administrative Order n. 431/2012, of December 31, 2012; Decree-Law n. 25/2013, of February 19, 2013; Decree-Law n. 153/2014, of October 20, 2014.

${ }^{12}$ We base this calculation on the Resolution of the Council of Ministers n. 20/2013, of April 10, 2013. This mentions the creation, in 2011, of a PV mini-production programme aiming to reach $250 \mathrm{MW}$ by 2020; and the intention to continue the PV micro-production programme and install more than $80 \mathrm{MW}$ by 2020 . As per statistics from DGEG, this segment was 82.7 MW in December 2012. Summing these figures $(250+80+82.7)$ yields 412.7 MW. A request for clarification to DGEG and the Secretariat of State for Energy had not resulted in a confirmation at the time of writing.

13 Details available on the Loulé municipality website, accessed on 19.02.2020 at http://www.cmloule.pt/upload_files/client_id_1/website_id_1/files/CML_Actas/2012/acta\%20n\%2018\%20de\%2029\%20de\%2 0Agosto\%20de\%202012.pdf. 
${ }^{14}$ EIA and EEA procedures establish an obligatory public consultation period, in which the Non-Technical Report is made available and written comments from private and public entities are received. However, participation in public consultation processes are usually very scarce. While NGOs and the local authorities are directly informed of the public consultation by the National Environment Agency, the local population is informed by local authorities, whose interests can be opposed to a wide public discussion of the project (e.g., Gonçalves, 2002).

15

Accessed

on

19.02.2020

at https://secure.avaaz.org/en/community_petitions/SAVE_MORGADO_DE_APRA_ALGARVE_PORTUGAL.

${ }^{16}$ Accessed on 19.02.2020 at http://siaia.apambiente.pt/AIADOC/AIA2827/pf\%20282720161417918.pdf.

${ }^{17}$ Via Algarviana is a Long-Distance Path (GR13) connecting Alcoutim to Cabo de São Vicente, at $300 \mathrm{Km}$ in length, mostly situated in the Algarve mountain. The route began to be created in 1995 by the Almargem association, in partnership with the Algarve Walkers, having been officially established in 2006 (http://www.viaalgarviana.org/index.php/o-projecto/historia/?lang=en).

18 The municipality of Alcoutim has already three PV concentration plants operating (totalling 3.4 MW), all installed in 2014. Besides, it is the chosen municipality for the construction of four more PV power plant projects: Pereiro (163.5 MW), Viçoso (48 MW), Albercas (28 MW) and São Marcos (49 MW).

${ }^{19}$ In the municipality of Alcoutim, by November 2019, there were 25 small tourist accommodations units, 4 of which in the parish of Vaqueiros, a hotel and an Inn of Youth, with a capacity to accommodate more than 300 people. There were also 16 tourist hunting areas, 2 of which in Vaqueiros, and 23 restaurants, 5 of which in Vaqueiros, as well as 3 tourist animation companies, 2 of which in the parish of Vaqueiros.

20 See http://almargem.org/site/index.php?option=com_content\&view=article\&id=142:2017-03-01-19-1902\&catid=13: noticias $\&$ Itemid=39.

${ }^{21}$ http://www.cm-moura.pt/wp-content/uploads/2019/03/PUCF_Declaracao_Ambiental.pdf.

${ }^{22}$ http://www.dgsi.pt/jstj.nsf/954f0ce6ad9dd8b980256b5f003fa814/8bde727c55527f288025790b0030cdd6.

${ }^{23}$ Amareleja is also the chosen parish for the construction of another PV power plant (14 MW), promoted by the company Hyperion Renewables Amareleja, whose public consultation process received no statements.

\section{References}

Appadurai, Arjun. 1996. Modernity at Large. Cultural Dimensions of Globalization. Minnesota: University of Minnesota Press. 
Argenti, Nicolas, and Daniel Knight. 2015. "Sun, Wind, and the Rebirth of Extractive Economies: Renewable Energy Investment and Metanarratives of Crisis in Greece." Journal of the Royal Anthropological Institute 21: 781-802. doi:10.1111/14679655.12287.

Bódis, Katalin, Ioannis Kougias, Nigel Taylor, and Arnulf Jäger-Waldau. 2019a. "Solar Photovoltaic Electricity Generation: A Lifeline for the European Coal Regions in Transition.” Sustainability 11, 3703. doi:10.3390/su11133703.

Bódis, Katalin, Ioannis Kougias, Arnulf Jäger-Waldau, Nigel Taylor, and Sándor Szabó. 2019b. "A High-Resolution Geospatial Assessment of the Rooftop Solar Photovoltaic Potential in the European Union." Renewable and Sustainable Energy Reviews 114, 109309. doi:10.1016/j.rser.2019.109309.

Bouzarovski, Stefan, and Neil Simcock. 2017. "Spatializing Energy Justice.” Energy Policy 107: 640-648. doi:10.1016/j.enpol.2017.03.064.

Bridge, Gavin, Stefan Bouzarovski, Michael Bradshaw, and Nick Eyre. 2013. "Geographies of Energy Transition: Space, Place and the Low-Carbon Economy.” Energy Policy 53: 331340. doi:10.1016/j.enpol.2012.10.06.

Brito, Miguel, João Serra, Jorge Alves, Killian Lobato, and António Vallêra. 2009. "Evaluation of the Implementation of PV Feed-In Law in Portugal." In Proceedings of the 24th European Photovoltaic Solar Energy Conference, September 21-25, 2009, Hamburg, Germany, At: Hamburg, 4435-4437.

Breukers, Sylvia, and Maarten Wolsink. 2007. "Wind Power Implementation in Changing Institutional Landscapes: An International Comparison.” Energy Policy 35 (5): 2737-2750. doi:10.1016/j.enpol.2006.12.004.

Brubaker, Rogers, and Frederik Cooper. 2000. “Beyond 'Identity”'. Theory and Society 29 (1): 1-47. doi:10.1023/A:1007068714468. 
Calvert, Kirby, and Warren Mabee. 2015. "More Solar Farms or More Bioenergy Crops? Mapping and Assessing Potential Land-Use Conflicts Among Renewable Energy Technologies in Eastern Ontario, Canada." Applied Geography 56: 209-221. doi:10.1016/j.apgeog.2014.11.028.

Campbell, Scott. 2016. “The Planner's Triangle Revisited: Sustainability and the Evolution of a Planning Ideal that Can't Stand Still.” Journal of the American Planning Association 82 (4): 388-397. doi:10.1080/01944363.2016.1214080.

Carlisle, Juliet, Stephanie Kane, David Solan, and Jeffrey Joe. 2014. “Support for Solar Energy: Examining Sense of Place and Utility-Scale Development in California.” Energy Research \& Social Science 3: 124-130. doi:10.1016/j.erss.2014.07.006.

Chase, Jenny. 2019. Solar Power Finance Without the Jargon. London: World Scientific Publishing Europe Ltd.

Cowell, Richard, Geraint Ellis, Fionnguala Sherry-Brennan, Peter Strachan, and David Toke. 2017. "Energy Transitions, Sub-National Government and Regime Flexibility: How has Devolution in the United Kingdom Affected Renewable Energy Development?" Energy Research \& Social Science 23: 169-181. doi:10.1016/j.erss.2016.10.006.

da Silva, Diogo, and Lummina Horlings. 2020. “The Role of Local Energy Initiatives in CoProducing Sustainable Places.” Sustainability Science 15: 363-377. doi:10.1007/s11625019-00762-0.

del Río, Pablo, and Mercedes Burguillo. 2008. “Assessing the Impact of Renewable Energy Deployment on Local Sustainability: Towards a Theoretical Framework." Renewable and Sustainable Energy Reviews 12 (5): 1325-1344. doi:10.1016/j.rser.2007.03.004.

Delicado, Ana, Elisabete Figueiredo, and Luís Silva. 2016. "Community Perceptions of Renewable Energies in Portugal: Impacts on Environment, Landscape and Local 
Development." Energy Research \& Social Science 13: 84-93. doi:10.1016/j.erss.2015.12.007.

Delicado, Ana, Mónica Truninger, Elisabete Figueiredo, Luís Silva, Luís Junqueira, Ana Horta, Susana Fonseca, Maria Nunes, and Filipa Soares. 2015. Terras de Sol e de Vento. Dinâmicas Sociotécnicas e Aceitação Social das Energias Renováveis em Portugal. Lisbon: Imprensa de Ciências Sociais.

DGEG. 2018. Renováveis. Estatísticas Rápidas, n. ${ }^{\circ}$ 159. Lisbon: DGEG.

DGEG. 2019. Renováveis. Estatísticas Rápidas, n. ${ }^{\circ}$ 176. Lisbon: DGEG.

Dunlap, Alexander. 2019. Renewing Destruction. Wind Energy Development, Conflict and Resistance in a Latin American Context. London and New York: Rowman \& Littlefield International.

Eriksen, Thomas. 2016. Overheating. An Anthropology of Accelerated Change. London: Pluto Press.

European Commission. 2007. Special Eurobarometer 262 / Wave EB65.3 - Energy Technologies: Knowledge, $\quad$ Perceptions, $\quad$ Measures. http://ec.europa.eu/public_opinion/archives/ebs/ebs_262_en.pdf (accessed on 16.09.2019).

European Commission. 2019. Portugal. Integrated National Energy and Climate Plan 20212030. https://ec.europa.eu/energy/sites/ener/files/documents/pt_final_necp_main_en.pdf (accessed on 15.07.2020).

European Union. 2019. Special Eurobarometer 490 / Wave EB91.3 - Climate Change. https://ec.europa.eu/commfrontoffice/publicopinion/index.cfm/survey/getsurveydetail/ins truments/special/surveyky/2212 (accessed on 16.06.2020).

Eurostat. 2018. Energy, Transport and Environmental Indicators. Luxembourg: Publications Office of the European Union. 
Gailing, Ludger, Andrea Bues, Kristine Kern, and Andreas Röhring. 2019. "Socio-Spatial Dimensions in Energy Transitions: Applying the TPSN Framework to Case Studies in Germany." Environment and Planning A: Economy and Space 0 (0): 1-19. doi:10.1177/0308518X19845142.

Garrod, Brian, Roz Wornell, and Ray Youell. 2006. "Re-Conceptualising Rural Resources as Countryside Capital: The Case of Rural Tourism." Journal of Rural Studies 22 (1): 117128. doi:10.1016/j.jrurstud.2005.08.001.

Gonçalves, Maria. 2002. "Implementation of EIA Directives in Portugal: How Changes in Civic Culture are Challenging Political and Administrative Practice.” Environmental Impact Assessment Review 22: 249-269. doi:10.1016/S0195-9255(02)00005-7.

Grossmann, Katrin. 2019. "Using Conflicts to Uncover Injustices in Energy Transitions: The Case of Social Impacts of Energy Efficiency Policies in the Housing Sector in Germany." Global Transitions 1: 148-156. doi:10.1016/j.glt.2019.10.003.

Howe, Cymene. 2014. “Anthropocenic Ecoauthority: The Winds of Oaxaca.” Anthropological Quarterly 87 (2): 381-404. doi:10.1353/anq.2014.0029.

Howe, Cymene, and Dominic Boyer. 2016. "Aeolian Extractivism and Community Wind in Southern Mexico.” Public Culture 28 (2 [79]): 215-235. doi:10.1215/08992363-3427427. Huber, Matthew. 2015. “Theorizing Energy Geographies.” Geography Compass 9 (6): 327338. doi:10.1111/gec3.12214.

INEGI/APREN. 2019. e2p Endogenous Energies of Portugal, Database of Electric Power Plants Based on Renewable Energy Sources, http://e2p.inegi.up.pt (accessed on 17.09. 2019).

Jäger-Waldau, Arnulf. 2020. "Snapshot of Photovoltaics - February 2020.” Energies 13 (4), 930. doi:10.3390/en13040930. 
Junqueira, Luís, Ana Delicado, and Mónica Truninger. 2017. "Paisagem, Tecnologia e Desenvolvimento Local. A Central Solar da Amareleja." Sociologia, Problemas e Práticas 83: 137-156. doi:10.7458/SPP2017837629.

Klusáček, Petr, Marek Havlíček, Petr Dvořák, Josef Kunc, Stanislav Martinát, and Petr Tonev. 2014. "From Wasted Land to Megawatts: How to Convert Brownfields into Solar Power Plants (The Case of the Czech Republic)." Acta Universitatis Agriculturae et Silviculturae Mendelianae Brunensis 62 (3): 517-528. doi:10.11118/actaun201462030517.

Kougias, Ioannis, Katalin Bódis, Arnulf Jäger-Waldau, Fabio Monforti-Ferrario and Sándor Szabó. 2016. "Exploiting Existing Dams for Solar PV System Installations.” Progress in Photovoltaics: Research and Applications 24 (2): 229-239. doi:10.1002/pip.2640.

McDonald, Robert, Joseph Fargione, Joe Kiesecker, William Miller, and Jimmie Powell. 2009. “Energy Sprawl or Energy Efficiency: Climate Policy Impacts on Natural Habitat for the United States of America.” PloS one 4 (8): e6802. doi:10.1371/journal.pone.0006802.

Mehnen, Nora, Ingo Mose, and Dirk Strijker. 2013. "Governance and Sense of Place: Half a Century of a German Nature Park." Environmental Policy and Governance 23 (1): 46-62. doi:10.1002/eet.1592.

Pasqualetti, Martin. 2004. "Wind Power: Obstacles and Opportunities." Environment: Science and Policy for Sustainable Development 46 (7): 22-38. doi:10.1080/00139150409604395. Pasqualetti, Martin. 2011. "Social Barriers to Renewable Energy Landscapes." The Geographical Review 101 (2): 201-223. doi:10.1111/j.1931-0846.2011.00087.x.

Prados, María. 2010. “¿Energías Renovables o Agricultura? Un Análisis de la Percepción Ciudadana sobre los Huertos y Latifundios Solares en Andalucía.” Nimbus 25-26: 205229. 
Ribeiro, Fernando, Paula Ferreira, Madalena Araújo, and Ana Braga. 2014. "Public Opinion on Renewable Energy Technologies in Portugal." Energy 69: 39-50. doi:10.1016/j.energy.2013.10.074.

Ryser, Sarah. 2019. "The Anti-Politics Machine of Green Energy Development: The Moroccan Solar Project in Ouarzazate and Its Impact on Gendered Local Communities.” Land 8, 100: 1-21. doi:10.3390/land8060100.

Sareen, Siddharth. 2020. "Metrics for an Accountable Energy Transition? Legitimating the Governance of Solar Uptake." Geoforum 114: 30-39. doi:10.1016/j.geoforum.2020.05.018.

Sareen, Siddharth, and Håvard Haarstad. 2018. "Bridging Socio-Technical and Justice Aspects of Sustainable Energy Transitions." Applied Energy 228: 624-632. doi:10.1016/j.apenergy.2018.06.104.

Sareen, Siddharth, Timothy Moss, Christian Lund, Håvard Haarstad, Benjamin Sovacool, and Steven Wolf. 2020. "Conclusion: Legitimation and Accountability in Energy Transitions Research.” In Enabling Sustainable Energy Transitions, edited by Siddharth Sareen, 117135. Cham: Palgrave Macmillan.

Scheer, Hermann. 2004. The Solar Economy: Renewable Energy for a Sustainable Global Future. London: Earthscan.

Silva, Luís, and Ana Delicado. 2017. "Wind Farms and Rural Tourism: A Portuguese Case Study of Residents' and Visitors' Attitudes and Perceptions." Moravian Geographical Reports 25 (4): 248-256. doi.10.1515/mgr-2017-0021.

Smith, Jessica, and Mette High. 2017. "Exploring the Anthropology of Energy: Ethnography, Energy and Ethics.” Energy Research \& Social Science 30: 1-6. doi:10.1016/j.erss.2017.06.027. 
Sovacool, Benjamin. 2013. Energy and Ethics: Justice and the Global Energy Challenge. New York: Palgrave Macmillan.

Sowers, Jacob. 2006. "Fields of Opportunity: Wind Machines Return to the Plains." Great Plains Quarterly 26 (2): 99-112.

Szabó, Sándor, Katalin Bódis, Ioannis Kougias, Magda Moner-Girona, Arnulf Jäger-Waldau, Gábor Barton, and László Szabó. 2017. “A Methodology for Maximizing the Benefits of Solar Landfills on Closed Sites." Renewable \& Sustainable Energy Reviews 76: 12911300. doi:10.1016/j.rser.2017.03.117.

Vartiainen, Eero, Gaëtan Masson, Christian Breyer, David Moser, and Eduardo Román Medina. 2020. "Impact of Weighted Average Cost of Capital, Capital Expenditure, and Other Parameters on Future Utility-Scale PV Levelised Cost of Electricity." Progress in Photovoltaics: Research and Applications 28 (6): 439-453. doi:10.1002/pip.3189.

Walker, Götz. 2014. "Determining the Local Acceptance of Wind Energy Projects in Switzerland: The Importance of General Attitudes and Project Characteristics." Energy Research \& Social Science 4: 78-88. doi:10.1016/j.erss.2014.09.003.

Watts, Laura. 2018. Energy at the End of the World: An Orkney Islands Saga. Cambridge, MA: The MIT press.

Weselek, Axel, Andrea Ehmann, Sabine Zikeli, Iris Lewandowski, Stephan Schindele, and Petra Högy. 2019. “Agrophotovoltaic Systems: Applications, Challenges, and Opportunities. A Review." Agronomy for Sustainable Development 39 (4), 35. doi:10.1007/s13593-019-0581-3.

Yenneti, Komali, Rosie Day, and Oleg Golubchikov. 2016. "Spatial Justice and the Land Politics of Renewables: Dispossessing Vulnerable Communities through Solar Energy Mega-Projects.” Geoforum 76: 90-99. doi:10.1016/j.geoforum.2016.09.004. 